\title{
Yield and Water Productivity of Capsicum under Different Concentrations of Treated Municipal Wastewater
}

\author{
Shahid Hameed Khan Khali1 ${ }^{1}$, Adnan Shakeel ${ }^{1}$, Ghani Akbar ${ }^{1}$, Muhammad Asif ${ }^{2}$, Ashraf Khan ${ }^{3 *}$ and \\ Zafar Islam ${ }^{1}$
}
${ }^{1}$ CEWRI, NARC, Pakistan Agricultural Research Council, Islamabad, Pakistan; ${ }^{2}$ NRD, Pakistan Agricultural Research Council, Islamabad, Pakistan; ${ }^{3}$ Institute of Plant and Environmental Protection, NARC, Islamabad, Pakistan.

Abstract | The use of wastewater in agriculture sector is growing worldwide because freshwater resources are depleting. Waste water is considered suitable for growing vegetables after appropriate treatment. A field experiment was conducted to investigate the yield response factor of capsicum to different concentrations of municipal wastewater treatments through bioremediation. Four irrigation treatments were applied by using potable and wastewater in different ratios. These treatments were $\mathrm{T}_{1}, \mathrm{~T}_{2}, \mathrm{~T}_{3}$ and $\mathrm{T}_{4}(100 \%$ treated wastewater, $66 \%$ treated wastewater and $34 \%$ potable water, $34 \%$ treated wastewater and $66 \%$ potable water and $100 \%$ potable water respectively). In treatment $\mathrm{T}_{1}$ the highest yields and crop water productivities of capsicum were 46.43 tons $/ \mathrm{ha}$ and $9.43 \mathrm{Kg} / \mathrm{m}^{3}$ in 2017 while 46.56 tons/ha and $9.49 \mathrm{Kg} / \mathrm{m}^{3}$ were obtained in 2018 respectively Results showed that yield response factor and water productivity of capsicum irrigated with treated waste water was 18\% and 16\% in 2017 and 2018 respectively which was higher than potable water. The level of essential nutrients in the waste water is higher as compared to potable water. From results it was concluded that waste water can be used for growing capsicum for increasing yield and water productivity.

Received | January 28, 2020; Accepted | September 01, 2021; Published | October 23, 2021

*Correspondence | Ashraf Khan, Institute of Plant and Environmental Protection, NARC, Islamabad, Pakistan; Email: ashraf_ento60@yahoo. com

Citation $\mid$ Khalil, S.H.K., A. Shakeel, G. Akbar, M. Asif, A. Khan and Z. Islam. 2021. Yield and water productivity of capsicum under different concentrations of treated municipal wastewater. Pakistan Journal of Agricultural Research, 34(4): 819-823.

DOI | https://dx.doi.org/10.17582/journal.pjar/2021/34.4.819.823

Keywords | Capsicum, Wastewater, Water productivity, Bioremediation, Yield

\section{Introduction}

$\mathrm{T}$ he available water resources are depleting and planners are compelled to search for alternate options, which might be used economically and effectively to cope with the emerging situation. At the same time, with population expanding at a high rate, the need for increased food production and in turn water consumption is apparent (Murtaza and Zia, 2012).

Among others, reuse of treated municipal wastewater may be a viable option. It is estimated that 4.36 billion cubic meters $(\mathrm{BCM})$ of wastewater is generated annually in Pakistan, Out of which industrial waste- water is $1.30 \mathrm{BCM} /$ year and domestic wastewater is 3.06 BCM/year (Izhar-ul-Haq, 2017).

If planned properly, use of municipal wastewater eliminates surface water pollution problems and not only conserves valuable water resources, but, also the nutrients contained in sewage are beneficial to grow crops (Tamer et al., 2014).

Use of wastewater in agriculture has significant benefits, but can also pose considerable risks to human health especially when untreated wastewater is used for irrigating crops. Wastewater percolation into groundwater aquifer can cause environmental risks in the form of soil and groundwater pollution. However, 
after proper treatment according to irrigation quality standards, irrigation with wastewater can have several benefits for the environment, as well as for agriculture and water resources management (Plevich et al., 2012). In wastewater, treated through bioremediation, a significant reduction was observed in parameters, e.g. BOD5 (98\%), COD (98\%), turbidity (100\%), odour (100\%) and pathogens (100\%) (Ahmed and Riffat, 2018).

The technologies which are being used for wastewater treatment include high-temperature incineration and different types of chemical decomposition. They can be very effective at reducing levels of a range of contaminants, but have several drawbacks, principally their technological complexity, the cost for smallscale application, and the lack of public acceptance. Bioremediation is a viable option which may be used for wastewater treatment. It is comparatively low-cost technology, which can easily be maintained and hence have a high public acceptance (Lone and Kirmani. 2018).

Bioremediation is a process used to treat wastewater by altering environmental conditions to stimulate growth of microorganisms and degrade the target pollutants.

Keeping in view the current water scarcity scenario and importance of reuse of treated municipal wastewater, this study was carried out to evaluate the effect of reuse of municipal wastewater, treated through bioremediation, on yield and water productivity of capsicum.

\section{Material and Methods}

\section{Site description}

Field experiments were conducted at Climate, Energy \& Water Research Institute (CEWRI) field station, National Agricultural Research Center (NARC) $\left(33.4^{\circ} \mathrm{N}, 73.8^{\circ} \mathrm{E}\right.$, and elevation of $498 \mathrm{~m}$ above mean sea level) under rain-out shelter. The soil of the site is silt loam with $28-33 \%$ field capacity. The climate is classified as semi-arid with hot-dry summer and cold winters. The average annual rainfall is $1200 \mathrm{~mm}$ out of which 750-800mm occurs during monsoon (PMDC, 2018). The daily and total crop water requirements of the crop under study are shown in Table 1.

A bioremediation garden (also known as constructed wetland) was constructed at the aforementioned site. The wastewater from NARC offices and officers' colony is diverted to screening filter from where it is automatically pumped into the bioremediation garden. The facility was designed and implemented by National Institute of Bioremediation, NARC to treat 50,000 US Gallons/day of wastewater generated.

Table 1: Daily and total crop water requirements of capsicum.

$\begin{array}{llllll}\text { Month } & \text { May } & \text { June } & \text { July } & \text { August September } \\ \text { CWR (mm/day) } & 2.6 & 2.87 & 4.52 & 5.84 & 3.93 \\ \text { Days } & 10 & 30 & 31 & 31 & 15 \\ \text { Total CWR (mm) } & 26 & 86 & 140 & 181 & 59\end{array}$

Source: PMDC, Karachi and UNO, WFO, Cropwater Program, 1931-2015.

\section{Experimental treatments and land preparation}

The field experiments were carried out using a RCB design comprising of four irrigation treatments; $\mathrm{T}_{1}$ (100\% treated wastewater), $\mathrm{T}_{2}$ (66\% treated wastewater and $34 \%$ potable water), $\mathrm{T}_{3}(34 \%$ treated wastewater and $66 \%$ potable water $)$ and $\mathrm{T}_{4}(100 \%$ potable water) as shown in Table 2. Treatments were three times replicated bearing a plot size of $7 \mathrm{~m} \times 3 \mathrm{~m}$.

\section{Table 2: Experimental treatments.}

$\begin{array}{llll}\text { Treatment } & \begin{array}{l}\text { Treated Waste- } \\ \text { water }(\mathbf{m m})\end{array} & \begin{array}{l}\text { Potable Water } \\ (\mathbf{m m})\end{array} & \text { Total }(\mathbf{m m}) \\ \mathrm{T}_{1} & 492 & 0 & 492 \\ \mathrm{~T}_{2} & 325 & 167 & 492 \\ \mathrm{~T}_{3} & 167 & 325 & 492 \\ \mathrm{~T}_{4} & 0 & 492 & 492\end{array}$

A local variety of capsicum, "C. annuum" was exploited as Test crop. After two months of sowing date, the capsicum plants were shifted to experimental field. The plants spacing was kept $40 \mathrm{~cm}$. The rows were spaced $50 \mathrm{~cm}$ apart as shown in Figure 1.

Before plants transplantation, basic soil parameters were determined fom the entire field by selecting different sampling sites (total 03 sites) as presented in Table 3.

The soil properties from randomly selected points were same and hence, the results would not be confounded.

Similarly, three wastewater samples were collected 
from bioremediation garden and tested in laboratory. The data obtained is shown in Table 4.

Table 3: Average soil physical parameters at the experimental site.

$\begin{array}{lllll}\begin{array}{l}\text { Soil layers } \\ (\mathbf{c m})\end{array} & \text { Texture } & \begin{array}{l}\text { Bulk density } \\ \left(\mathbf{g} / \mathbf{c m}^{3}\right)\end{array} & \begin{array}{l}\text { Field ca- } \\ \text { pacity }(\mathbf{\%})\end{array} & \begin{array}{l}\text { Wilting } \\ \text { point } \mathbf{( \% )}\end{array} \\ 0-20 & \text { Silt loam } & 1.29 & 27.7 & 11.3 \\ 20-60 & \text { Silt loam } & 1.46 & 33.3 & 12.7\end{array}$

Table 4: Wastewater treated through bioremediation.

$\begin{array}{lllll}\text { Parameter } & \text { Unit } & \begin{array}{l}\text { Permissible } \\ \text { Limit }\end{array} & \text { Inlet } & \text { Outlet } \\ \text { Ph } & & 6.5-8.5 & 8.03 & 7.48 \\ \mathrm{EC} & \mu \mathrm{S} / \mathrm{cm} & 0-3000 & 1826.56 & 1369.63 \\ \mathrm{TDS} & \mathrm{mg} / \mathrm{L} & 0-2000 & 653.24 & 546.11 \\ \mathrm{BOD} & \mathrm{mg} / \mathrm{L} & 80 & 148 & 52.06 \\ \mathrm{COD} & \mathrm{mg} / \mathrm{L} & 150 & 206.81 & 58.19 \\ \text { Bicarbonate } & \mathrm{mg} / \mathrm{L} & 0-610 & 548.44 & 460.56 \\ \text { Chloride } & \mathrm{mg} / \mathrm{L} & 0-1065 & 68.84 & 58.83 \\ \text { Nitrate } & \mathrm{mg} / \mathrm{L} & 0-30 & 2.93 & 1.29 \\ \text { Sulphate } & \mathrm{mg} / \mathrm{L} & 0-960 & 74.46 & 56.26 \\ \begin{array}{l}\text { Fecal Coli- } \\ \text { forms }\end{array} & \mathrm{MPN} / 100 \mathrm{~mL} & 0-1000 & >16000 & 223.75 \\ \text { Total Coli- } & \mathrm{MPN} / 100 \mathrm{~mL} & 0-1000 & >16000 & 355.63 \\ \text { forms } & & & & \end{array}$

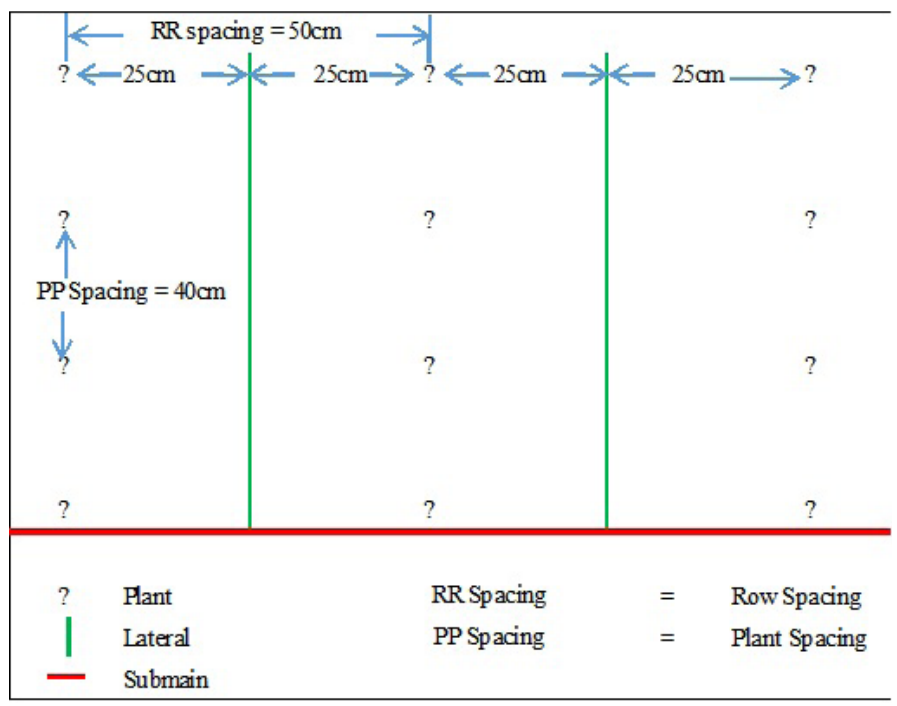

Figure 1: Experimental layout of sub-plot.

\section{Irrigation application}

Before plantation, the plants were irrigated using installed integrated drip irrigation. The laterals were installed between every other crop row at a space of $50 \mathrm{~cm}$. Irrigation water requirement was calculated by using AquaCrop 6.0 model developed by FAO. Standard procedure was followed to calculate the crop water requirement by using 10 years weather data. The weather data was collected from weather station installed at NARC. The experimental blocks were kept at field capacity throughout the growing season. 30\% MAD was allowed for the crop under study (Maughan, et al., 2015). As per Crop Water Requirement, water was applied on daily basis using laterals (Jain brand, India made) with 2LPH of drippers discharge at a spacing of $40 \mathrm{~cm}$. Soil water content was deliberated using gravimetric method.

\section{Harvesting of crop}

There were six rows in each sub-plot. The $2^{\text {nd }}, 3^{\text {rd }}, 4^{\text {th }}$ and $5^{\text {th }}$ rows were harvested. Averages of the picked fruits were worked out and yield was calculated for hectare.

\section{Yield and water productivity}

Yield of the total fruits of the capsicum harvested in different pickings from the sample plants in each treatment was recorded and averages were worked out and it was calculated for hectare.

1. Total water used in each irrigation treatment was calculated by using following formula and expressed as $\mathrm{mm}$.

2. Total water used $(\mathrm{mm})=$ water applied at all irrigations $(\mathrm{mm})+$ rainfall $(\mathrm{mm})$.

3. As the experiment was conducted in rainout shelter, hence, rainfall ( $\mathrm{mm}$ ) was omitted.

4. Water productivity (WP) is the ratio between fruit yield to the amount of water used. It was worked out by using the following formula and expressed as $\mathrm{kg} \mathrm{ha} \mathrm{m}^{-1} \mathrm{~mm}^{-1}$.

5. $\mathrm{WP}=$ yield obtained $(\mathrm{kg}) /$ water applied

\section{Results and Discussions}

\section{Water quality parameters}

The wastewater collected in screening chamber of bioremediation garden comprises of grey water (from washrooms) and black water (from toilets). Thus, it is contaminated with detergents and organic matter which is fatal for human health. The main parameters, which are considered in wastewater for safe use in agriculture, include BOD, COD, Fecal Coliforms and Total Coliforms (Jeong et al., 2016).

The BOD, COD, Fecal Coliforms and Total Coliforms of raw water collected in screening chamber were $148 \mathrm{mg} / \mathrm{L}, 206.81 \mathrm{mg} / \mathrm{L},>16000 \mathrm{MPN} / 100 \mathrm{~mL}$ 
and $>16000 \mathrm{MPN} / 100 \mathrm{~mL}$ respectively. The permissible limits are $80 \mathrm{mg} / \mathrm{L}, 150 \mathrm{mg} / \mathrm{L}, 0-1000 \mathrm{MP}-$ $\mathrm{N} / 100 \mathrm{~mL}$ and $0-1000 \mathrm{MPN} / 100 \mathrm{~mL}$ respectively (NEQS, 2018).

It is clear from Table 4, that the quality parameters of sample collected from outlet (treated wastewater) are in permissible limit and hence safe for agricultural use.

\section{Yield and water productivity}

The yield and crop water productivity obtained for each treatment in 2017 and 2018 are shown in Table 5.

Table 5: Bell pepper yield Eं water productivity for different treatments.

\begin{tabular}{lllll} 
Treatment & Year 2017 & \multicolumn{3}{c}{ Year 2018 } \\
& $\begin{array}{l}\text { Yield } \\
\text { (tons/ha) }\end{array}$ & $\begin{array}{l}\text { WP }(\mathrm{Kg} / \\
\mathrm{m}^{3} \text { ) }\end{array}$ & $\begin{array}{l}\text { Yield } \\
\text { (tons/ha) }\end{array}$ & $\mathrm{WP}\left(\mathrm{Kg} / \mathrm{m}^{3}\right)$ \\
$\mathrm{T}_{1}$ & $46.43 \mathrm{a}$ & $9.43 \mathrm{a}$ & $46.56 \mathrm{a}$ & $9.49 \mathrm{a}$ \\
$\mathrm{T}_{2}$ & $46.30 \mathrm{a}$ & $9.42 \mathrm{a}$ & $46.35 \mathrm{a}$ & $9.44 \mathrm{a}$ \\
$\mathrm{T}_{3}$ & $43.31 \mathrm{~b}$ & $8.74 \mathrm{~b}$ & $43.48 \mathrm{~b}$ & $8.72 \mathrm{~b}$ \\
$\mathrm{~T}_{4}$ & $39.49 \mathrm{c}$ & $8.12 \mathrm{c}$ & $39.61 \mathrm{c}$ & $8.12 \mathrm{c}$ \\
$\mathrm{LSD}(5 \%)$ & 2.5156 & 0.1870 & 0.6076 & 0.2660
\end{tabular}

In the years 2017 and 2018 the results are significantly different. In both years the highest yield and productivity were obtained for the treatment $\mathrm{T}_{1}$. Similarly, the lowest yield and productivity were obtained for the treatment $\mathrm{T}_{4}$ in the years 2017 and 2018.

It was observed that yield and water productivity of capsicum irrigated with treated wastewater water was $18 \%$ and $16 \%$ higher than that irrigated with potable water in the years 2017 and 2018 respectively.

The results confirm to the findings of Lone and Kirmani (2018), who also identified similar yield trends for Capsicum by using bio-remediated wastewater and the reason was attributed to high nutrient content of wastewater.

The results are in right alignment with Suhad et al. (2018). He concluded that wetlands can be applied successfully for domestic sewage treatment. Moreover, the corresponding system effluent can subsequently be recycling for irrigating chillies used to treated wastewater, when grown in organic growth media. ference in the results. In treatments $T_{1}$ tap water was used for irrigation which did not contain nitrates (nutrient content). In $\mathrm{T}_{2}$ on the other hand only a little portion of wastewater, containing nutrients, was used. Hence, the yields and productivities for both the treatments were almost same.

In $\mathrm{T}_{4}$ the whole irrigation was carried out using treated wastewater which contained the beneficial nutrients, that's why, it resulted in better yield and productivity as compared to the other treatments.

The same findings were achieved by Garcia et al. (2012). According to him, the purified urban wastewater treatment supplied enough nutrients to obtain yield and fruit quality equal to that of natural groundwater with fertilization. There was a significant saving on N, P and $\mathrm{K}$ fertilizers (37\%, 66\% and $12 \%$ respectively), achieved by using purified urban wastewater.

\section{Conclusions and Recommendations}

This work has shown the prospects of increased production and reduced disposal of untreated wastewater, which may lead to reduced deterioration of surface and ground water resources. Moreover, this research has shown huge potential for profitable use of wetlands for increasing agricultural production. The use of municipal wastewater treated through bioremediation and subsequent recycling of the treated wastewater for irrigation of crops such as Capsicum annum can be a good substitute to conserve the available freshwater for drinking purposes. This recycling approach can help in saving the precious fresh water resources and thus lead to reduce irrigation water demands.

Keeping in view the water saving and productivity potential of waste water, it is recommended that long term field experiments needs to conducted for identifying the benefits under changing environmental conditions.

\section{Novelty Statement}

As far as the authors are aware, there is no similar research work carried out related to identify the yield and water productivity of capsicum irrigated with treated municipal wastewater.

In treatments $T_{1}$ and $T_{2}$ there is no significant dif- 
Author's Contribution

Shahid Hameed Khan Khalil: Conceived the idea, conducted literature review, synthesize the data, wrote the paper and presented the results, discussions and conclusions while utilizing his field experience and research background.

Adnan Shakeel: Being environmental engineer, supported in conducting water quality tests in light of PSQCA standards.

Ghani Akbar: Supported in literature review and improving language of manuscript.

Muhammad Asif: Supported in data collection and data compilation.

Ashraf Khan and Zafar Islam: Supported in field experimentation and data analysis.

\section{Conflict of interest}

The authors have declared no conflict of interest.

\section{References}

Ahmed, S. and R. Riffat.2018. Small Scale Sewage Treatment and Wastewater Reuse System for Pakistan. Department of Microbiology Quaidi-Azam University, Islamabad, Pakistan

Tamer, A.E., T.A., N. Bakr, F. Karajeh and D. El Quosy. 2014. Treated wastewater utilization for agricultural irrigation in Egypt. pp. 3546. In: Proceedings of the national conference on Water Quality: Challenges and Solutions. National Research Centre-Cairo, Egypt. http:// bio-nrc.jimdo.com/conferences/.

García, C.D., E. Eymar, J.I. Contreras and M.L. Segura. 2012. Effects of fertigation with purified urban wastewater on soil and pepper plant (Capsicum annuum L.) production, fruit quality and pollutant contents. Spanish J. Agric. Res. 10(1): 209-221. https://doi.org/10.5424/ sjar/2012101-065-11
Izhar-ul-Haq. 2017. World water day: National policy on sustainable use of wastewater urged.

Jeong, H., H. Kim and T. Jang. 2016. Irrigation water quality standards for indirect wastewater reuse in agriculture: A contribution toward sustainable wastewater reuse in South Korea. 8(4): 169. https://doi.org/10.3390/w8040169

Lone, A.F and N.A. Kirmani. 2018. Growth and yield of Capsicum annum under irrigation with different levels of domestic wastewater. J. Curr. World Environ. 13(2): 77-84. https://doi. org/10.12944/CWE.13.2.13

Murtaza, G. and M.H. Zia. 2012. Wastewater production, treatment and use in Pakistan. Final Country Report, Pakistan.

Maughan, T., D. Drost and L.N. Allen. 2015. Vegetable irrigation: Sweet pepper and tomato. Horticulture Department, Utah State University.

National Environmental Quality Standards of Pakistan, 2018.

Plevich, O.J., Delgado, S.A.R., Saroff, C., Tarico, J.C., Crespi, R.J. and Barotto, O.M. 2012. Bioremediation of wastewater for reutilization in agricultural systems. J. App. Ecol. Environ. Res. 16(12): 1353-1358. https://doi.org/10.1590/ S1415-43662012001200013

PMDC, Karachi and UNO, WFO, Cropwate Program, 1931-2015. 2018.

Ahmad, S. and R. Riffat. 2018. Small scale sewage treatment and wastewater reuse system for Pakistan.

Suhad, A.A.A., N. Almuktar, S.N. Abed and M. Scholz. 2018. Contaminations of soil and two capsicum annuum generations irrigated by reused urban wastewater treated by different reed beds. Int. J. Environ. Res. Public Health. 15(8): 1776-1800. https://doi.org/10.3390/ ijerph15081776 